\title{
An Assessment of Potential Zones for Food Security using Vegetation Indices
}

Richard J. U. ${ }^{1}$, Ibochi Andrew Abah ${ }^{2}$

${ }^{1}$ Head Business Development, Office of the Surveyor General, Moscow Road, Port Harcourt, Nigeria, jeremiah.uriah@yahoo.com

${ }^{2}$ Department of Surveying \& Geoinformatics Federal Polytechnic, Bauchi, Nigeriam, arndewabah4real@gmail.com

\section{Abstract}

Food is the basic need of man and even animals. It is essential for the growth of the body tissues and cells. Food insecurity may be cause by war, disease outbreak, poor agricultural management practice, drought, deforestation etc. Food insecurity was experienced in Ozuzu in 1995 and Egbu in 1993 all in Etche Local Government Area due to prolong dry season. The long dry season affected the production of maize, yam, cassava, etc. which are the main source of food and income in the area. This study was designed to evaluate potential zones for food security through remote sensing and GIS technology. It was carried out using Landsat 8 OLI of 2017 data and ESRI's ArcGIS 10.1 software for processing and computation of MSI and VSWI which are two vegetation indices selected for identifying potential zones for food security. The computed MSI and VSWI were reclassified into five classes ranging from very good to very poor potential zones. The results show that MSI perform optimally in identifying potential zones for food security in the study area. For the MSI, the very good potential zones ranges from $0.118-0.170$ and were located along the river banks of Otamirioche, Ogueche and Imo River, Siat palm plantation and in some isolated locations in the north. Similarly, very poor zone ranges from $0.325-0.376$ and occurred in the built-up areas mostly in the southern map location. Food insecurity menace in the study area can be address using remote sensing data and GIS software to analysis vegetation for potential zone for cultivations. For further study, more indices should be integrated in the determination of potential zones for food security.

Keywords: Food Security, Land Surface Temperature, MSI, NDVI, OLI Landsat 8, Potential Zones, VSWI.

\subsection{Introduction}

Food, shelter and clothing are the basic needs of man for daily living. Of these three needs, food becomes the most important requirements by man because man and even animals cannot survive without food. Food is defined as substance whether in liquid, concentrated, solid, frozen, dried, or dehydrated form, that are sold for ingestion or chewing by humans and are consumed for their taste or nutritional value [1]. Food helps to build our tissues, new cells, prevent and fight against infectious disease and to live and look healthy. Base on the above mentions importance of food, it is also better to secure its production and distribution in any given state. Food security is defined as a situation that exists when everyone (male and female), at all times, have physical, social and economic access to sufficient, safe and 
nutritious food that meets their dietary needs and food preferences for an active and health life [2]. It main driving factors are; affordability, availability, quality and safety [3]. Food security is measure by global food security index (GFSI) on a scale of $0-100$ and Nigeria was 34.8 on the index [4]. Food security is now global concern due to rapid increase in population and the climate change effects. Food insecurity can be cause by overpopulation, oil spill, deforestation and climate change [5]. The most affected climate change impact was in agricultural sector [6]. The outbreak of epidermis such as Ebola in West Africa also leads to food insecurity [7]. The Boko Haran attacks in Northeast Nigeria are another contributor to food insecurity. [8] Reported that over 795 million people are undernourished with majority of them in Africa and Asia. Experts have reported that over 70 percent of Nigeria population was under-nourished.

Food security is a multi-discipline approach [9], and all professionals including remote sensing and GIS most be fully integrated. It is through remote sensing and GIS that locations or individual (living in towns, villages or cities) that have food security can be ascertain. Similarly, remote sensing and GIS will equally depict spatially food insecure areas and their inhabitants. To ensure food security, the nation's agricultural systems must be revolutionized [10]. Remote sensing is capable of overhauling agricultural sector by providing platforms that accessed all parts of the globe within limited time and at relatively low cost. [11]; [12] elucidate the application of remote sensing in agriculture. Remote sensing can be used to monitor food supply, demand and early warning for imminent food crisis [13]; [14]. The US developed famine early warning system in 20 African countries, especially, in the semi-arid region to provide adequate and accurate information on food security [14]. [16] Stated the important of remote sensing in rangeland forage assessment food security. [17] Used remote sensing data to derived NDVI in monitoring rice production for food security in Bangladesh. [18] Used NDVI derive from AVHRR data, soil moisture and sea surface temperature to study vegetation anomalies for food security in India. Also, [19] Study climate variation and crop growth on food security in Nepal using NDVI derived from MODIS data, rainfall and temperature dataset. Using only one vegetation index may not be enough for vegetation analysis for food security. Hence, moisture stress index (MSI) which determine the amount of soil moisture and vegetation supply water index (VSWI) which determine the presence of drought condition where used to determine potential zones for food security (locations that can ensure continuous supply of food production base on the available soil moisture and water supply). The following objectives were advance; (a) to determine potential zones for food security using moisture stress index and vegetation supply water index derived from Landsat satellite image and (b) to determine the spatial relationship between land surface temperature (LST) against MSI and VSWI using correlation analysis derived from the sample points $(\mathrm{x}, \mathrm{y}, \mathrm{z})$.

\subsection{Study Area}

Etche L.G.A., Rivers State, Nigeria is located on $274185 \mathrm{mE}-307185 \mathrm{mE}$ and $541125 \mathrm{mN}-$ $580065 \mathrm{mN}$ in WGS84, Zone 32N. It has an approximate area of 85059 ha with a total population of 249,454 people [20]. The area was selected for the study due to its food potential to the entire state. It hosts many agricultural farms and plantation notably the Siat Group Limited palm tree plantation that created hundredths employment opportunities and the ongoing ADAMA farm project operated by Israelis 1r- Group of Company on 5,000 hectares of land. Also, in Okomoko, rubber processing plant called the Delta Rubber Factory was established but has since dormant due to government negligence. The people of Etche 
ethnic group are predominantly farmers, producing cash crops such as yam, cassava, palm oil, plantain, banana, pineapple, etc. The area is traversed southward by fresh water of Imo River, westward by Otamirioche River, and Ogueche River [21]. These rivers provide water needed for irrigation of farmlands for enhancing food security of the state. The average temperature ranges from $30.0^{\circ} \mathrm{C}-33.0^{\circ} \mathrm{C}$ and annual rainfall ranges between $2100 \mathrm{~mm}-$ $4600 \mathrm{~mm}$ [22]. The favourable climate encourages continuous food production in the area. According to [23] it has soil that is red-yellow ferrasols on loose sandy sediments. Ferralsols contains high concentration of iron(III), aluminum oxides and hydroxides which give red or yellowish color, in addition they also contain quartz and kaolin, plus small amounts of other clay mineral sand organic matter. The study area map was shown in Figure 1.

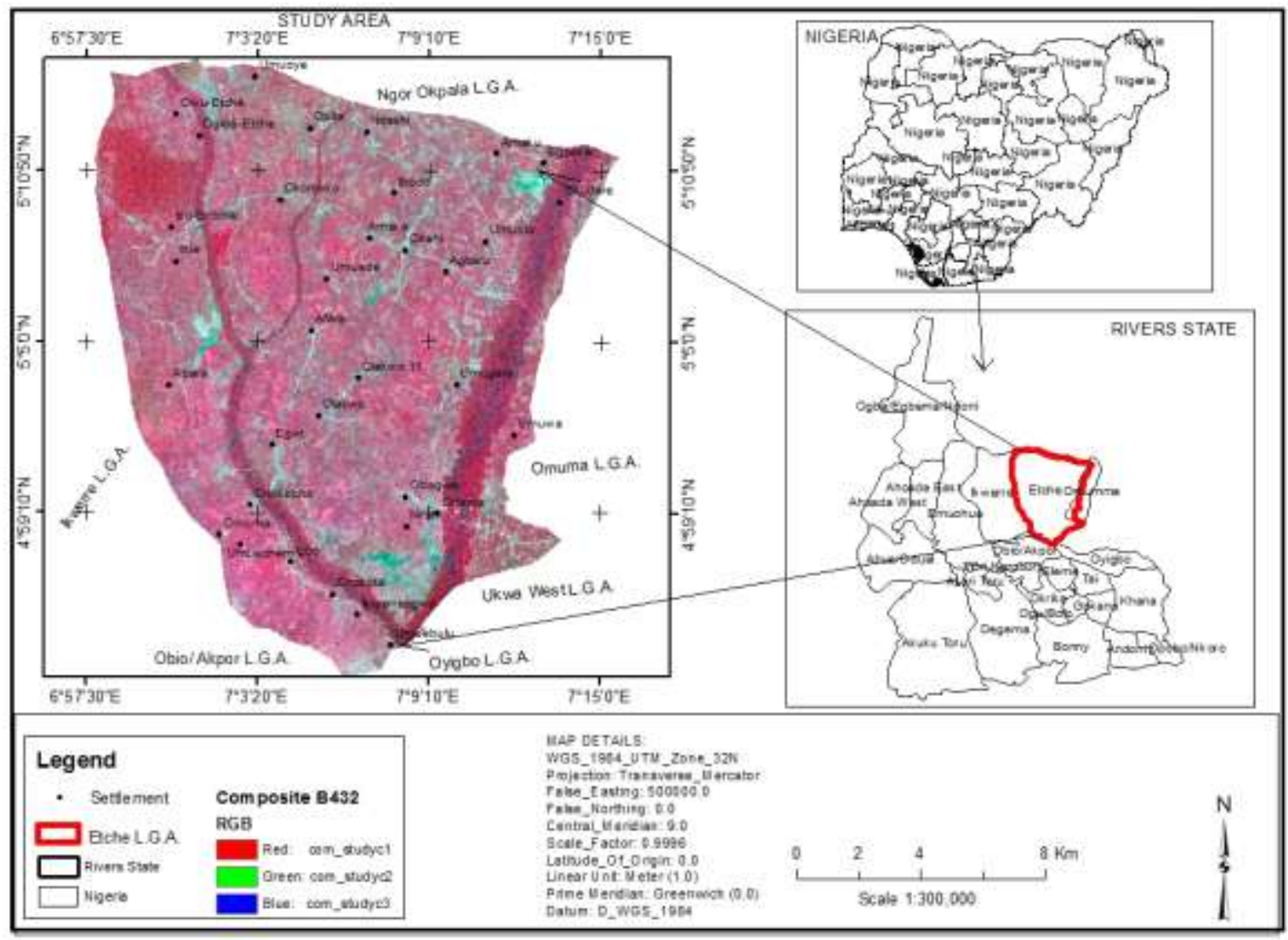

Figure 1. Map of the study area prepared from Landsat image.

\subsection{Methodology}

The assessment of potential zones for food security was carried out using Landsat image of 2017 which was downloaded from its website using scene path and row. The image was corrected for both geometric and radiometric distortions by the data provider. However, only conversion of digital number (DN) to TOA radiance was perform on the remotely sensed image data. This is necessary so as to analysis the image base on actual reflectance from the earth's surface features. The conversion was performed on all the bands utilized for the study. These bands were used to compute moisture stress index (MSI) and vegetation supply water index (VSWI) which are two indices for assessing potential food security zones in the study area. Site survey was conducted in the area using extracted coordinates from the potential 
food security zones. The study was carried out using the methodology flow chart as shown in figure 2 .

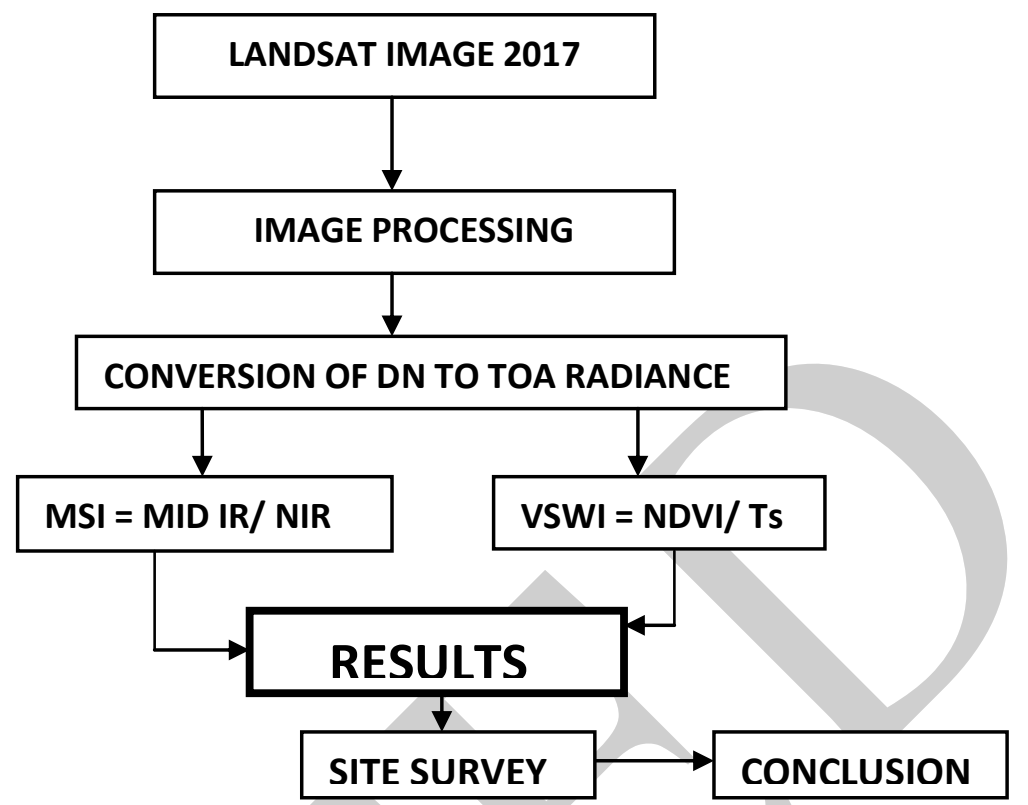

Figure 2. Methodology flow chart for identifying potential zones for food security.

\subsection{Software and Dataset Used}

Several remote sensing and GIS software may be used to analysis data for food security monitoring. The choice of software depends on the user's ability and the availability of such software. ESRI's ArcGIS 10.1 software was selected because it contained tool for raster calculations for evaluating quantitative models. The software strength is in vector data processing but suitable for map algebra. It was used to perform image clipping, conversion of DN to TOA radiance, derivation of vegetation indices (moisture stress index and water supply vegetation index) [24]; [25] and for the compilations of maps. Vegetation indices can also be derived using Environment for Visualizing Images (ENVI) software [26] and PANCROMA $^{\mathrm{TM}}$ [27]. PANCROMA ${ }^{\mathrm{TM}}$ can be purchase at subsidized rate from the web link www.PANCROMA.com. SPSS was used to compute correlation coefficient of the variables. The study was carried out using Landsat 8 OLI acquired on $6^{\text {th }}$ January 2017 . Landsat data was selected because it is freely available for research purposes and contained bands for vegetation analysis. The Landsat imageries were downloaded from its website (http://glovis.usgs.gov/) using path 188 and row 57 in zip file. It also contained header file for image metadata. The Landsat image selected for download was the precision orth-corrected product (LIT) that has been corrected for radiometric and geometric distortions [28]. Image was acquired in GMT but was processed in Nigeria local time zone. Also, settlement and Etche L.G.A. shape files were obtained from OSGRV on request. Table 1 shows the characteristics of the Landsat data used in the study.

Table 1. Characteristics of Landsat data used for the study.

\begin{tabular}{|c|c|c|c|c|}
\hline Sensor & Acqui. Date & Acqui. Time & Band and Range $(\mu \mathrm{m})$ & Resolution (m) \\
\hline Landsat OLI & $1 / 6 / 2017$ & $10: 45: 23$ & $\begin{array}{l}\mathrm{B} 3=\mathrm{GREEN}=0.53-0.59 \\
\mathrm{~B} 4=\mathrm{RED}=0.64-0.67 \\
\mathrm{~B} 5=\mathrm{NIR}=0.85-0.88 \\
\mathrm{~B} 6=\mathrm{SWIR}-1=1.57-1.65 \\
\mathrm{~B} 10=\text { TIR-1 }=10.60-11.19\end{array}$ & $\begin{array}{l}30 \times 30 \\
, \\
, \\
, \\
\text { Resample }\end{array}$ \\
\hline
\end{tabular}




\subsection{Data Processing}

Processing of remote sensing data is the first phase of any research involving satellite data. The image was reshaped from the base bands to reflect the extent of the study area [29]. Landsat image bands selected for the study are band 4, 5, 6 and 10 respectively. These bands were selected because band 5 and 6 is for healthy vegetation and band 10 is the thermal infrared band [28]. Band 4, 5 and 6 of the image has $30 \mathrm{~m} \times 30 \mathrm{~m}$ spatial resolutions and band 10 has $100 \mathrm{~m} \times 100 \mathrm{~m}$ spatial resolution [28]. But band 10 was resampled to $30 \mathrm{~m} \times 30 \mathrm{~m}$ resolution by the data provider prior to the data download. This was necessary to ensure uniform pixel cell size in all bands and to enhance further data analysis. All Landsat data have been georeferenced to WRS-1 \& 2 at the base station. The WRS-2 was used to reference all Landsat OLI, TM and ETM+ [28]; [30]. The referenced system was adopted for this study. Similarly, radiometric correction of the satellite image was based on the data source.

However, in computing vegetation indices for food security assessment, the image was converted from digital number (DN) to Top of atmosphere (TOA) radiance which represents the actual reflectance from the earth's surface. The DN (also called digital count or gray value) is a dimensionless unit and does not represent any physical quantity [31], hence, the need for its conversion. The conversion of image from DN to TOA radiance follows the formulae quoted in the Landsat user's guide and the metadata parameters.

Landsat OLI conversion to TOA radiance is computed using the formula in Landsat user's guide given as,

$\mathrm{L}_{\lambda}=\mathrm{M}_{\mathrm{L}} \times \mathrm{Q}_{\mathrm{cal}}+\mathrm{A}_{\mathrm{L}}$

Where, $\mathrm{L}_{\lambda}$ is the spectral radiance in $\mathrm{Wm}^{-2} \mathrm{Sr}^{-1}, \mathrm{M}_{\mathrm{L}}$ is the radiance multiplicative scaling factor for the band, $\mathrm{Q}_{\mathrm{cal}}$ is the $\mathrm{L} 1$ pixel value in $\mathrm{DN}$ and $\mathrm{A}_{\mathrm{L}}$ is the radiance additive scaling factor for the band [28]. The parameters were obtained from the Landsat header file containing all the bands in the sensor.

\subsubsection{Vegetation Indices (VIs)}

Two vegetation indices were computed from the Landsat image for the determination of potential zones for food security. The two indices are moisture stress index (MSI) and vegetation supply water index (VSWI). Moisture stress index (MSI) was developed by Hunt Jr and Rock, 1989 and the equation was given by,

Mid IR / NIR

Where Mid IR is the Mid-infrared band and NIR is the near infrared band of the sensor [32]. This study used Landsat 8 OLI image for MSI calculation [33], where mid infrared is the band 6 and near infrared is the band 5. MSI as the name suggest is used for the analysis of leaf stress and crop productivity [33]. Its values ranges from 0 to more than 3 with the higher values indicate greater plant water stress as a consequence of less soil moisture contents. Green and healthy vegetation usually falls in the range of 0.2 to 2 [32]. Soil moisture is defined as the volume of water content in the soil. It is generally influence by the type of soil and surface temperature. Also influence by soil hydrology [34]. Soil moisture is a key factor in agriculture and help farmers to increase production [35] for the sustenance of food security. It can be determine by gravimetric (in-situ measurement) and remote sensing method. The remote sensing method is based on the reflected radiation from the leave surface. If the soil moisture is deficient, the chlorophyll content in the plant leave will reduce, indicating stressed plant [36]. In addition, photosynthetic ability of plant will be affected, 
thereby impacting on the food security of the affected areas. The following researchers have applied MSI in agriculture; [37] used MSI and others indices in soil salinity and hydrological drought mapping and [38] used MSI and others indices derived from hyperspectral data to study near surface temperature of peatland ecosystems.

Similarly, vegetation supply water index (VSWI) developed by [39] was given by, NDVI/ Ts

Where NDVI is the Normalized difference vegetation index and Ts is the remote sensing image estimated brightness temperature expressed in Celsius scale. NDVI was first proposed by Reuse et al, 1974 [40] and was computed using the equation,

NDVI $=($ Near infrared - Red $) /($ Near infrared + Red $)$

Where Near infrared band is the band 5 and red band is the band 4 in the Landsat OLI data. NDVI values ranges from -1 to 1 [12] which indicates the variations of green and healthy vegetation type in the given area. The higher NDVI value the denser the vegetation and the lower NDVI the less dense or absent of vegetation cover. Accordingly, Ts was computed from the TOA radiance image using the formula,

$\mathrm{Ts}=\mathrm{K} 2 / \operatorname{In}\left(\mathrm{K} 1 / \mathrm{L}_{\lambda}+1\right)$

Where, Ts is the TOA brightness temperature in Kelvin, $\mathrm{L}_{\lambda}$ is the spectral radiance in Wm ${ }^{2} \mathrm{Sr}^{-1}, \mathrm{~K} 1=774.89 \mathrm{~K}$ and $\mathrm{K} 2=1321.08 \mathrm{~K}$ are the thermal constants for band 10 . The parameters $\mathrm{M}_{\mathrm{L}}, \mathrm{A}_{\mathrm{L}}, \mathrm{K} 1$, and $\mathrm{K} 2$ were obtained from the Landsat header file. The Kelvin scale image was converted to Celsius scale before applying in the model using the relationship,

$\mathrm{C}=\mathrm{Ts}-273.15$

Where, Ts is the Kelvin temperature, and $\mathrm{C}$ is the Celsius temperature. The value $273.15^{\circ} \mathrm{C}$ is the absolute zero temperature for converting Kelvin scale to Celsius scale.

From equation 3, a lower value of VSWI indicates the presence of drought condition [41]. The index was designed to study the effects of drought on leaf canopy. [42] highlighted some drought indices such as normalized multiband drought index (NMDI), apparent thermal inertia (ATI), vegetation condition index (VCI), vegetation health index (VHI), drought severity index (DSI), crop water stress index (CWSI), temperature - vegetation drought index (TVDI) etc.

The values of MSI, NDVI, LST and VSWI was extracted using sample tool as points in $\mathrm{x}, \mathrm{y}$, $\mathrm{z}$ (where $\mathrm{x}$ and $\mathrm{y}$ is the horizontal coordinate and $\mathrm{z}$ is the vegetation indices vertical component). It was extracted base on pixel with vegetation indices values as the vertical component (z). A total of 945,102 points (x, y, and z) was extracted from each map and was used for correlation analysis. Correlation analysis provides a means of measuring the strength of relationship between variables (dependent and independent). It is validated using correlation coefficient $(\mathrm{r})$ which provides standardized measure of linear association between variables [43]. The correlation coefficient (r) ranges from -1 to +1 [44]. For higher positive (r) there exist strong positive relationship, and higher negative indicates weak relationship. The (r) was computed using SPSS version 17.

\subsection{Presentation of Results and Discussion}

The results of the analysis for the determination of potential zones for food security in the study area were presented below using table and maps. The maps were reclassified into five 
classes for easy interpretation. Figure 3 is the moisture stress index (MSI) obtained from Landsat image of 2017 showing various potential zones for food security. Very good potential zones ranges from $0.118-0.170$ and was represented on the map with leaf green colour. The zones were found in the riparian vegetation of Otamirioche and Ogueche River, Siat palm tree plantation and some isolated locations on the map. This zone was followed by good potential food security which ranges from $0.170-0.221$, represented by quetzel green colour. The third class was the moderately good zone with values ranges from $0.221-0.273$, represented on the map in tourmaline colour. It is mostly located in the built-up areas. The last two zones are the poor and very poor zones ranges from $0.273-0.325$ and $0.325-0.376$ respectively. These zones are small in area compare to other three classes. The minimum, maximum and mean values of MSI are $0.118,0.378$ and 0.177 respectively as shown in table 2 .

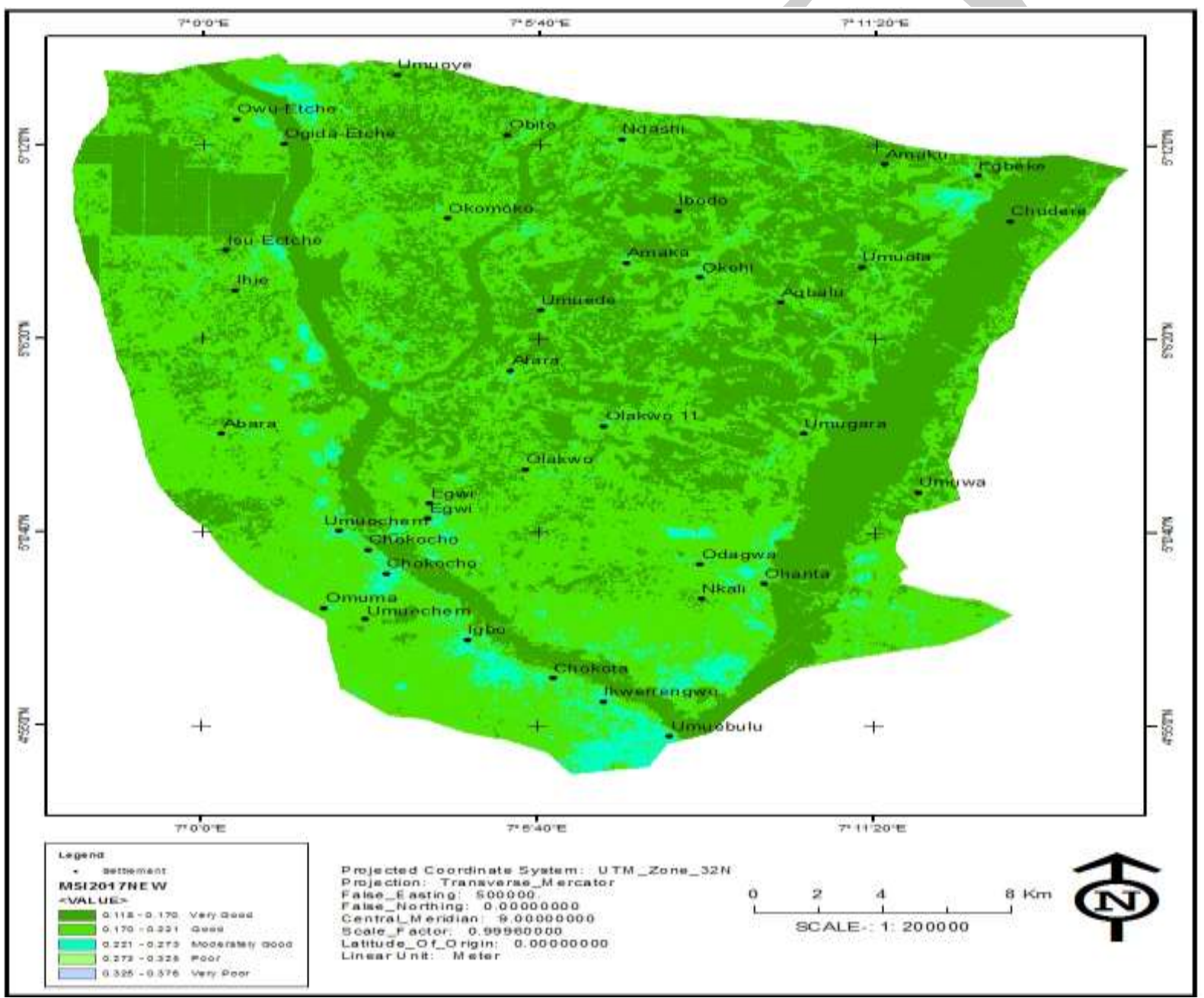

Figure 3. Moisture stress index (MSI) map derived from Landsat 2017 image used in the food security assessment.

Figure 4 is the NDVI map from which VSWI was computed. The minimum, maximum and mean NDVI values are $-0.237,0.246$ and 0.107 respectively as shown in table 2 . The very low or lack of green vegetation on the map ranges from $-0.237--0.140$ and was depicted in lemongrass colour. It was preceded with low green vegetation class that ranges from - 0.140 -0.044 and was represented with light apple colour. The moderately high and high green 
vegetation classes ranges from $-0.044-0.053$ to $0.053-0.150$ on the map. The last class was the very high green vegetation that ranges from $0.150-0.246$ and was represented with leaf green colour. It was mostly located in the northward and along the two main rivers.

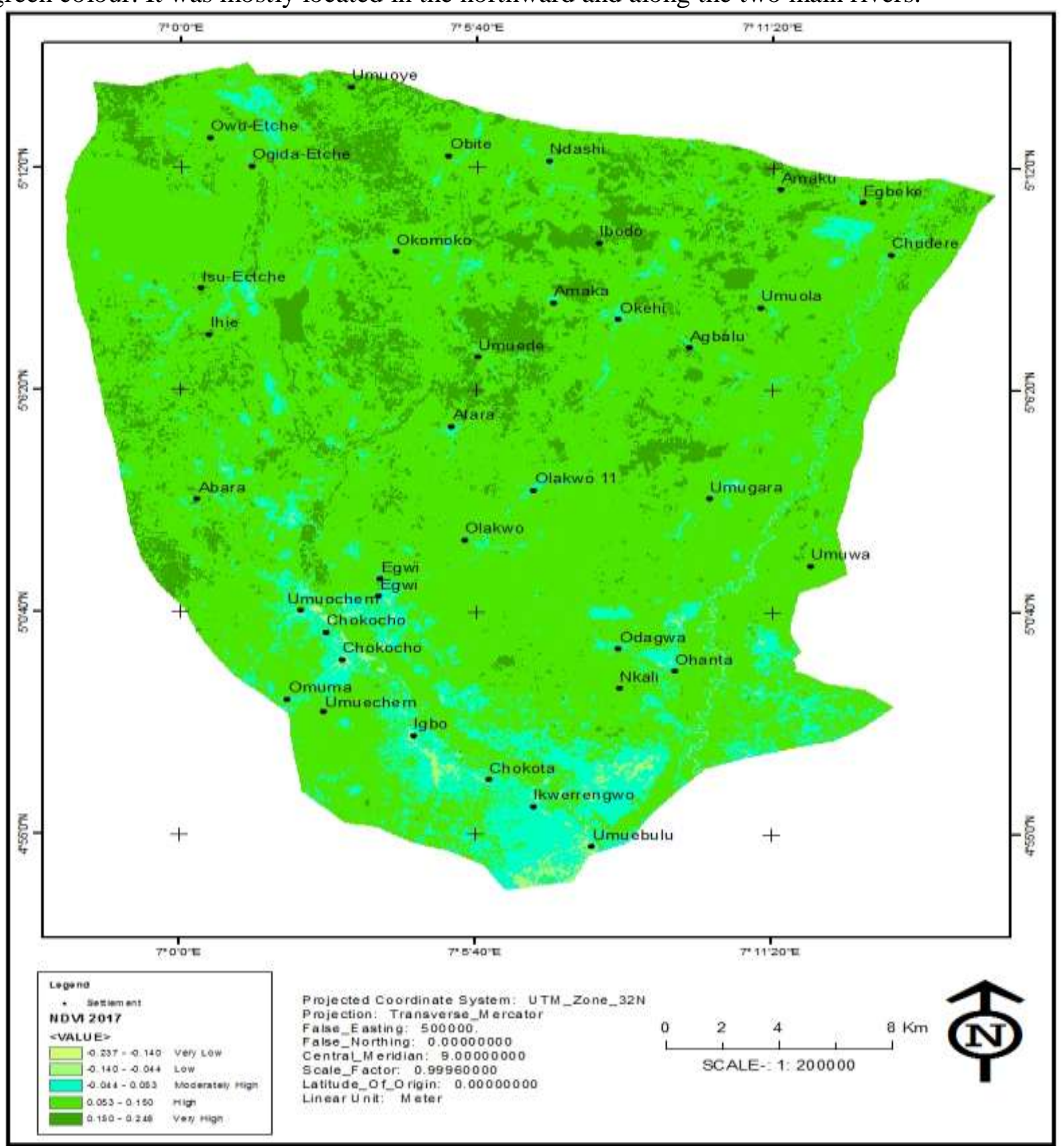

Figure 4. Computed normalized difference vegetation index (NDVI) map used for the derivation of vegetation supply water index (VSWI) from 2017 image.

Figure 5 was the derived land surface temperature from which VSWI was generated. The LST was reclassified into five classes ranging from very low to very high temperature. Very low class occurs in the range of $22.262-23.869^{\circ} \mathrm{C}$ and was depicted in autunite yellow colour. Low LST class ranges from $23.869-25.476^{\circ} \mathrm{C}$ as represented with fuchsia pink colour. Finally, very high LST class ranges from $28.691-30.298^{\circ} \mathrm{C}$ and was depicted on the map with mar red colour. 


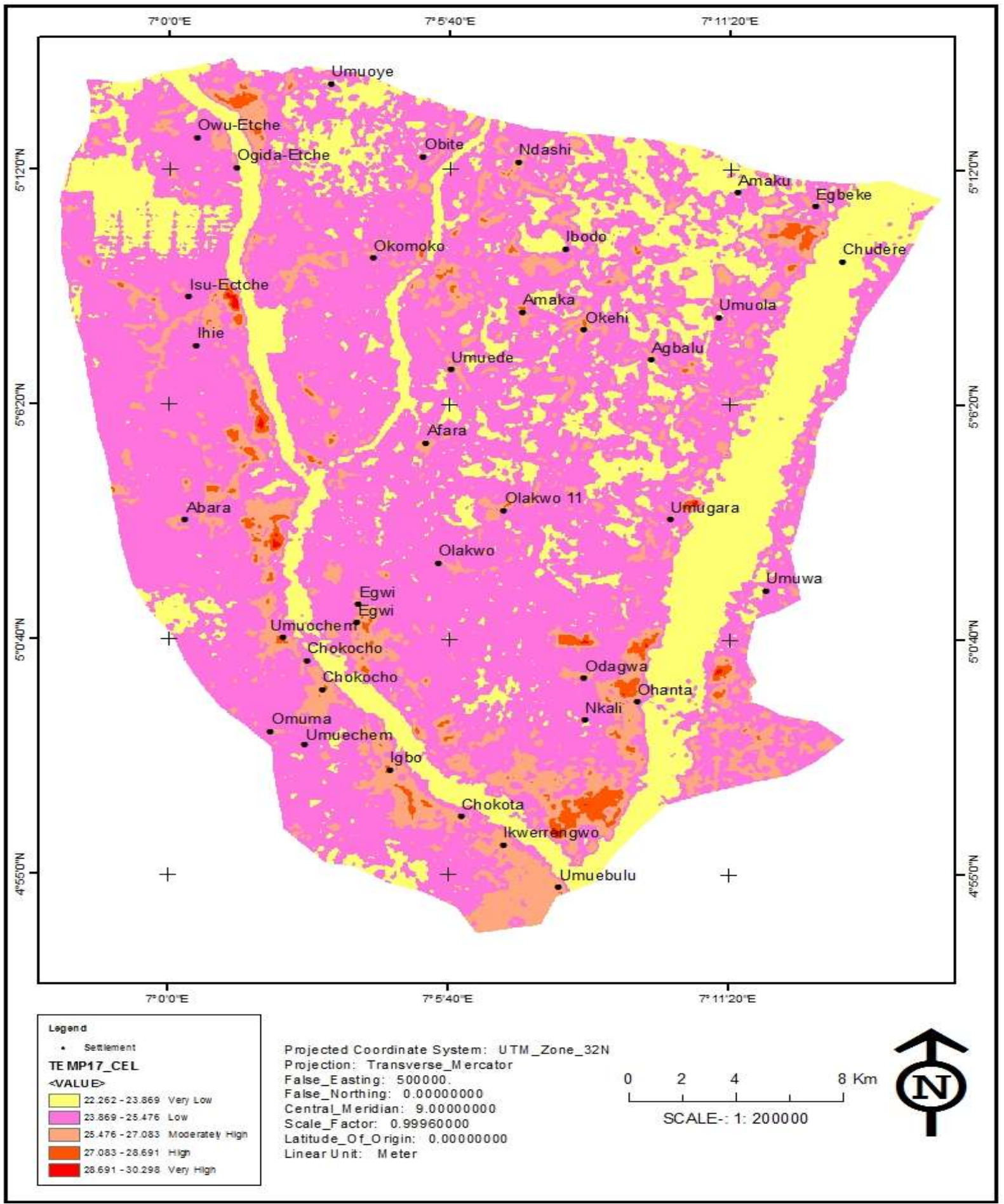

Figure 5. Computed LST map used for the derivation of vegetation supply water index (VSWI) from 2017 image.

The reclassified map of VSWI produced from NDVI and LST was shown in figure 6. The map was reclassified into five classes ranging from very poor (very high drought) to very good (very low drought) food potential zones. Very poor potential zone ranges from -0.010 -0.006 and was represented with fire red colour. It is located in the built-up areas with high human activities. The poor food security potential zone (high drought) ranges from -0.006 - - 
0.002 and was depicted on the map with fuchsia pink colour. This class was located within the neighbourhoods of built-up areas. The third class was the moderately good potential zone (moderately high drought) ranges from $-0.002-0.002$ which was shown on the map with sugilite sky colour. The good potential class ranges from $0.002-0.006$ and was represented with peridot green colour. This class occupies the greater percentage of the map. Finally, very good potential zone was in the range $0.006-0.011$ and was depicted on the map in leaf green colour. It was mostly located in northern part of the map such as Amaka, Umuede, Isu-Etche, Ibodo, Umuoye etc.

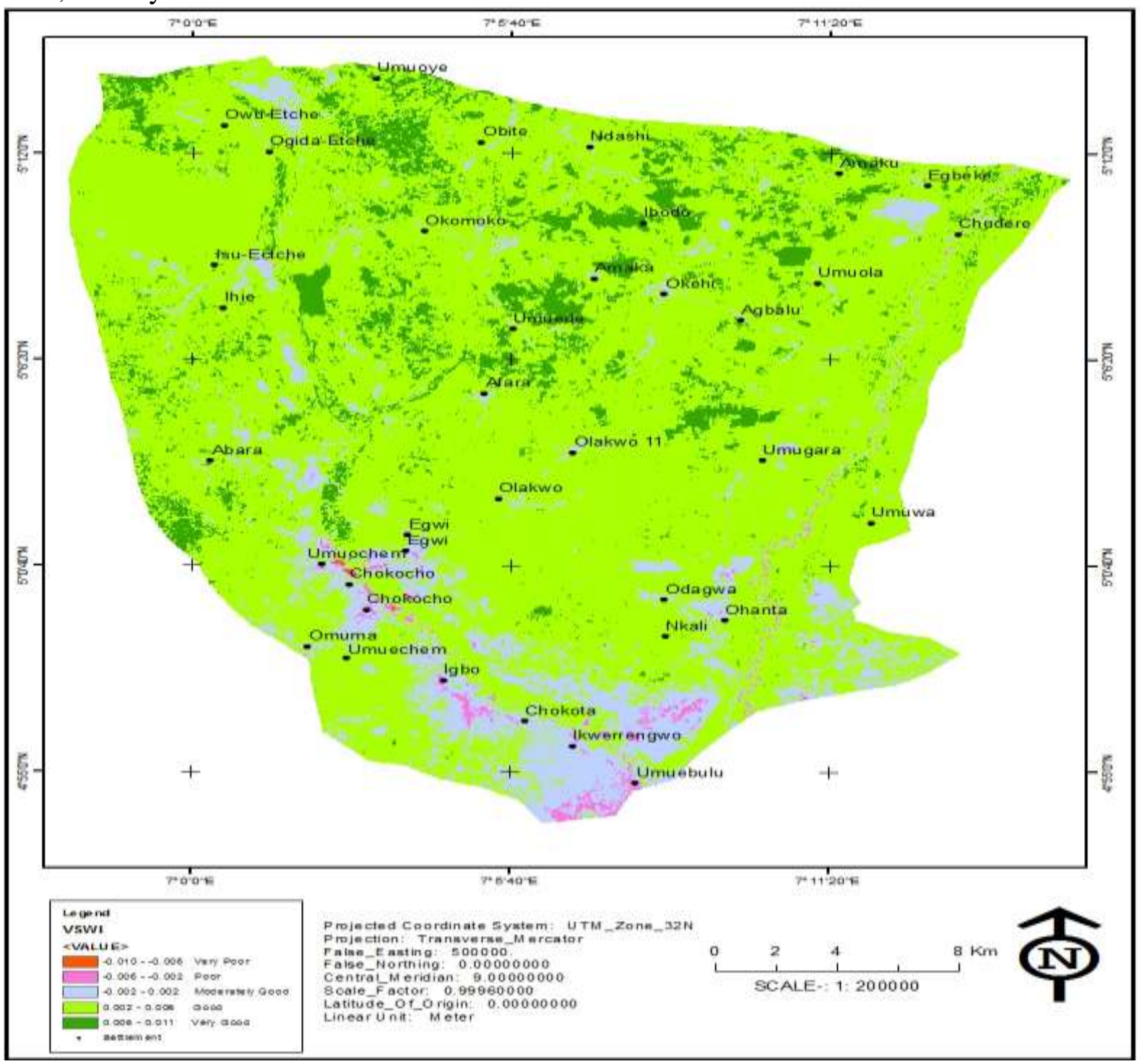

Figure 6. Vegetation supply water index (VSWI) map for vegetation drought mapping derived from NDVI and LST.

Table 2 shows the statistics of individual model. The statistics shows the minimum, maximum and mean values for each model derived from the image. The correlation coefficient (r) for MSI and VSWI was -0.668, MSI and LST was 0.865, LST and NDVI was 0.535 and VSWI and LST was -0.577. It was designed to evaluate the relationship between calculated quantities. 
Table 2. Model statistics of MSI, VSWI, LST and NDVI maps derived from Landsat 2017 image.

\begin{tabular}{|l|l|l|l|l|}
\hline \multirow{2}{*}{ STAT. } & \multicolumn{5}{|c|}{ DERIVED MAP } \\
\cline { 2 - 6 } & MSI & VSWI & LST $\left({ }^{\circ} \mathbf{C}\right)$ & NDVI \\
\hline MIN. & 0.118 & -0.010 & 22.26 & -0.237 \\
\hline MAX. & 0.376 & 0.011 & 30.30 & 0.246 \\
\hline MEAN & 0.177 & 0.004 & 24.49 & 0.107 \\
\hline $\mathbf{r}$ & MSI and VSWI $=-0.668$ & MSI and LST $=0.865$ & $\begin{array}{l}\text { LST and NDVI =- } \\
0.535\end{array}$ & $\begin{array}{l}\text { LST and VSWI =- } \\
0.577\end{array}$ \\
\hline
\end{tabular}

\subsection{Discussion}

MSI map shows very good zone which was located along the river banks, Siat palm tree plantation and some isolated locations on the map. The presence of soil moisture was due to proximity to water source such as the popular Otamirioche and Ogueche River that continuously flood the banks, especially, in the raining season. Secondly, the broad canopy of palm tree in Siat palm tree plantation in Isu-Etche and Ogida-Etche also prevent direct radiation of the earth's surface. The approximate area of Siat plantation in Etche only was 2293ha and extended to Ogueche River. Also in Ihie which is about $2 \mathrm{~km}$ from Siat plantation, very good zone was identified with an approximate area of $217 \mathrm{ha}$. In addition, the ADAMA farm project was situated on very good and good potential zones located in Olakwo 1 and 11, Odagwa, Umugara and Ohanta mainly in ensuring food security. The farm was located closed to Imo River which will contribute to soil moisture within the farm and also provides water for irrigation purpose. At present, the ADAMA farm has an approximate area of 86ha exclusively for cocoa productions. There were also available very good potential zones north of ADAMA farm that can support large scale productions of cash crops. This area extended from Afara to Ndashi settlements. These locations may support the cultivation of palm tree which has become the main source of income in Etche. One of the important palm tree by-products is palm oil which constitutes a source of income to the people. Palm oil is an essential ingredient in our diet [45] and we need to encourage its production. Others byproducts that may be obtained from palm tree plantation in these potential zones are soaps, candles, greases and lubricants, edible fats etc.

In the built-up areas food security will not be guarantee due to absent of soil water as a result of construction and urbanization. Urbanization exposes the soil to direct temperature, thereby affecting crop production. It also leads to soil compatibility and loss of soil flora and fauna. Soil compatibility increases the rate of runoff which reduces the amount of soil moisture needed for crop development.

VSWI responded same with MSI in assessing potential zone with an observable difference in class size. The major difference was that for the VSWI, Siat plantation was categorized as good potential zone while MSI categorized Siat plantation as very good potential zone for food security. Secondly, the total area represented as very good potential zone for the MSI was more in areal extent than that computed as very good potential zone in VSWI. Locations that have severe drought conditions become pronounce on the VSWI map. These locations are located within the built-up areas. This justified the fact that MSI is preferable in identifying potential zones for food security. The very good potential zones were located in Ihie, Umuede, Ibodo, west of Ibete and Umuola. These locations indicate absence of drought condition due to abundance of soil moisture that will encourage crop production for food security. They can support production of cash and food crops in all the seasons (dry and wet), considering the period in which the image was captured and the evidence from site survey. 
Negative relationships exist between MSI and VSWI which implies that an increase in one value leads to corresponding decrease in the other value. For instance, when MSI was 0.173 (very good potential zone) at location $279600 \mathrm{mE}, 579750 \mathrm{mN}$, the VSWI was 0.004 , indicating good zone. Similarly, at location $283350 \mathrm{mE}, 563820 \mathrm{mN}$, the MSI and VSWI was 0.208 and 0.004 respectively. The strong negative correlation coefficient (r) - 0.668 implies that as the soil moisture increase the soil drought condition becomes lesser. However, there is a strong positive relationship between MSI and LST, implying that an increase in soil moisture leads to corresponding decrease in LST. At location $303660 \mathrm{mE}$, 569880Mn, LST was $22.87^{\circ} \mathrm{C}$ while MSI was 0.149 (very good potential zone). Similarly, at location $294270 \mathrm{mE}, 546360 \mathrm{mN} \mathrm{LST}$ was $27.94^{\circ} \mathrm{C}$ while MSI was 0.235 (indicating moderately good potential zone).

\subsection{Conclusion}

Remote sensing technology offers solutions in addressing food security at global scale. Food insecurity may be cause over population, drought, deforestation, poor farm management practice, outbreak of epidemics such as ebola etc. Food insecurity is prevalent in Africa countries including Nigeria and other less developed nations in the world. With the advent of remote sensing and GIS and its applications in agriculture, effective management practice can be put in place to address food insecurity globally. This study utilized moisture stress index (MSI) and vegetation water supply index (VWSI) in assessing potential zones for food security in Etche Local Government Area, Rivers State, Nigeria. The study was conducted using Landsat 8 image converted from DN to TOA radiance and site survey data to analysis potential zones for food security. The study concluded that MSI produced better results than VSWI. MSI computed Siat plantation, greater portion of ADAMA farm and riparian vegetation along the river banks as very good potential zones for food security. It is recommended that further study should include the analysis of soil samples in all the potential zones for the determination of suitable site and soil type for a particular crop.

\subsection{References}

[1] Ohio Department of Taxation, ST 2004-01 - Food Definition, Business Tax Division Sales \& use Tax, Columbus Ohio, 43216-0530, www.tax.ohia.gov, pp. 1-9, 2015.

[2] FAO, WFP and IFAD, FAO, WFP and IFAD. 2012. The State of Food Insecurity in the World 2012. Economic growth is necessary but not sufficient to accelerate reduction of hunger and malnutrition. Rome, FAO, pp. 1 - 65, 2012.

[3] B. U. Joanna, D. C. Jennifer, B. B. Christopher, and H. D. Charles, Food Security as Resilience: Reconciling Definition and Measurement, School of Applied Economics \& Management, Cornell University, pp. 1 - 36, 2015.

[4] Global Food Security Index, An Assessment of Food Affordability, Availability, and Quality, a Report from the Economist Intelligence Unit, pp. 1-37, 2012.

[5] C. Njike, and O. Daniel, Leveraging Food Security Challenges in Eastern Nigeria using GIS and Geospatial Education, $8^{\text {th }}$ FIG Regional Conference, pp. $1-32,2012$.

[6] S. A. Erna, The Applications of Satellite Remote Sensing on Climate Change and Food Security in Indonesia, 53th Session of UN-COPUOS, Vienna/ June 9-18, 2010, pp. 1 - 40, 2010.

[7] T. Nkunzimana, E. Custodio, A. C. Thomas, N. Tefera, A. Perez Hoyos, and F. Kayitakire, Global analysis of food and nutrition security situation in food crisis hotspots, EUR 27879, pp. 1 - 98, 2016. doi:10.2788/669159. 
[8] United Nations Economic and Social Council, The Role of Science, Technology and Innovation in Ensuring Food Security by 2030, Commission on Science and Technology for Development Twentieth Session, Geneva, 8-12, May 2017, pp. 1 - 22, (2017).

[9] ECA, Enhancing the Effectiveness of Food Security Information Systems in SADC, Economic Commission for Africa Sub-regional office Southern Africa, pp. 1 - 48, 2011.

[10] E. Olivier, and B. Clemens, The Food Security System A New Conceptual Framework, International Food Policy Research Institute, pp. 1 - 20, 2012.

[11] A. K. Ali, Remote Sensing, $1^{\text {st }}$ Edition, Republic of Irag Ministry of Higher

Education and Scientific Research University of Technology, p4, 2010.

[12] M. R. Anji, The TextBook of Remote Sensing and Geographic Information Systems, $3^{\text {rd }}$ Edition, 4-4-309, Giriraj Lane, Sultan Bazar, Hyderabad-500 095-A.P, p92, 2008.

[13] R. Paul, Earth Observation for Agriculture Monitoring, Global Information and Early Warning System on Food and Agriculture (GIEWS), pp. 1 - 19, 2015.

[14] E. B. Molly, Satellite Remote Sensing in Agriculture and Food Security Assessment, Procedia Environmental Sciences, Vol. 29, pp. $307-315,2015$. doi: 10.1016/j.proenv.2015.07.278.

[15] EOS, Early Famine Warning Possible using Remote Sensing and Models, EOS, Transaction, American Geophysical Union, Vol. 88, (39), pp. 381 - 396, 2007.

[16] C. R. Matthew, A. Robert, A. Jay, E. H. Raymond, W. K. Ranjani, K. Lalit, L. Tatiana, L. Thomas, M. Graciela, and R. R. Douglas, Global View of Remote Sensing of Rangelands: Evolution, Applications, Future Pathways, pp. 238 - 274, 2016.

[17] B. Suraiya, and N. Mehrum, Remote Sensing Technology Contributions towards Food Security of Bangladesh, American Journal of Remote Sensing, Vol. 1, (3), pp. 67 - 71, 2013. doi: 10.11648/j.ajrs.20130103.12.

[18] A. Akarsh, and M. Vimal, Prediction of Vegetation Anomalies to Improve Food Security and Water Management in India, Geophys. Res. Lett., Vol. 42, pp. 5290 - 5298, 2015. doi:10.1002/2015GL063991.

[19] M. Q. Faisal, N. S. Shib, M. Murthy, B. Tina, D. Krishna, and G. H. Bishnu, Operationalizing Crop Monitoring System for Informed Decision Making Related to Food Security in Nepal, the International Archives of the Photogrammetry, Remote Sensing and Spatial Information Sciences, Vol. XL-8, ISPRS Technical Commission VIII Symposium, 09 - 12 December 2014, Hyderabad, India, pp. 1325 - 1230, 2014.

[20] National Bureau of Statistics, Official Gazette (FGP 71/52007/2500 OL24), National and State Provisional Total 2006 Census, 2006.

[21] A. A. Oluyemi, N. O. Comfort, A. E. Okom, O. Tokunbo, U. U. Sammy, and U. H. Edet, Seasonal Variation in the Physico-Chemical Characteristics of Surface Water in Etche River, Niger Delta Area of Nigeria, IOSR Journal of Environmental Science, Toxicology and Food Technology (IOSR-JESTFT), Vol. 8, (7), pp. 1-7, 2014.

[22] NIMET, Nigeria Climate Review Bulletin, pp. 1 - 40, 2011.

[23] FAO, World soil resources office in Cooperation with O.R.S.T.O.M., Land and Water resources Development Division/ FAO, pp. 1, 1964.

[24] J. F. Grant, and C. Lane, Calculating Vegetation Indices from Landsat 5 TM and Landsat 7 ETM+ Data, Lesson 10 of Colorado State University, pp. 1 - 18, 2011.

[25] I. Jonathon, Remote Sensing Observations of Central New York Green-up Phenology in April and May 2009, Monroe Community College, Rochester, NY, pp. 1 - 16, 2014.

[26] ENVI User's Guide, ENVI Version 4.1, Research System Inc, pp. 14, 2004. 
[27] C. John, Pancroma ${ }^{\mathrm{TM}}$ Satellite Image Processing Making Satellite Better ${ }^{\mathrm{TM}}$, Instruction Manual Version 101, pp. 1-399, 2012, www.PANCROMA.com.

[28] USGS, Landsat 8 (L8) Data Users Handbook LSDS-1574 Version 2.0, pp. 21 - 61, 2016.

[29] J. U. Richard, and O. Chima, Analysis of Impact of Land Use/ Land Cover Change in Oguta/ Orashi Watershed, International Journal of Emerging Trends in Engineering and Development, vol. 3, (6), pp. 21 - 34, 2016.

[30] Landsat Technical Guide, Global Land Cover Facility, University of Maryland Institute for Advanced Computer Studies, Department of Geography, http://ltpwww.gsfc.nasa.gov/IAS/handbook/handbook toc.html, pp. 1 - 2, 2004.

[31] G. Abduwasit, Calculating Surface Temperature using Landsat Thermal Imagery, Macelwane Hall 3243507 Laclede Ave, St Louis, MO 63103, pp. 1-9, 2010.

[32] R. E. Hunt Jr, and B. N. Rock, Detection of Changes in Leaf Water Content using Near and - Middle - Infrared Reflectances, Remote Sensing of Environment, Vol. 30, (1), pp. 43 54, 1989.

[33] P. Welikhe, E. Joseph, F. Souleymane, and M. Wendell, Estimation of Soil Moiture Percentage using Landsat based Moisture Stress Index, J. of Remote Sensing \& GIS, Vol. 6, (2), pp. $1-5,2017$.

[34] H. Vereecken, T. Kamai, T. Harter, R. Kasteel, J. Hopmans, and J. Vanderborght, Explaining Soil Moisture Variability as a Function of Mean Soil Moisture: A Stochastic Unsaturated Flow Perspective, Geophysical Research Letter, Vol. 34, pp. 1 - 6, 2007, doi:10.1029/2007GL031813.

[35] USGS, Methods of Measuring Soil Moisture in the Field, Geological Survey WaterSupply Paper 1619-U, pp. 1 - 29, 1992.

[36] M. Govender, PJ. Dye, IM. Weiersbye, ETF. Witkowski, and F. Ahmed, Review of Commonly used Remote Sensing and Ground - Based Technology to Measure Plant Water Stress, Water SA, Vol. 35, (5), pp. 741 - 751, 2009.

[37] E. Mohamed, and A. B. Jarbon, Soil Salinity Mapping and Hydrological Drought Indices Assessment in Arid Environments Based on Remote Sensing Techniques, Geosci. Instrum. Method. Data Syst, Vol. 6, pp. 149 - 158. 2017, doi:10.5194/gi-6-149-2017.

[38] M. M. Karl, J. F. Michael, S. K. Evans, R. P. Lynette, W. B. Brain, M. S. S. Alistair, L. B. Laura, and E. M. Marry, Spectral Detection of Near-surface Moisture Content and Watertable Position in Northern Peatland Ecosystems, Remote Sensing of Environment, Vol. 152, pp. $536-546,2014$.

[39] T. N. Carlson, E. M. Perry, and T. J. Schmugge, Remote Estimation of Soil Moisture Availability and Fractional Vegetation cover for Agricultural fields, Agricultural and Forest Meteorology, Vol. 52, pp. 45-69, 1990.

[40] G. S. Nikolaos, K. A. Thomas, Z. G. Ioannis, and P. Konstantinos, Vegetation Indices: Advances Made in Biomass Estimation and Vegetation Monitoring in the Last 30 Years, Geocarto International, Vol. 21, (4), pp. 1 - 8, 2006.

[41] R. C. S. Alvala, M. A. C. Anapaula, S. B. B. Sheila, E. S. Marcelo, A. M. Jose, L. L. M. Osvaldo, and A. C. Magog, Drought Monitoring in the Brazilian Semiarid Region, Annals of the Brazilian Academy of Sciences, pp. 1 - 15, 2017, http://dx.doi.org/10.1590/00013765201720170209.

[42] S. Abbas, Understanding Vegetation Moisture and Rainfall Relationship Leading towards Integrated Drought Index from Remote Sensing, The Hong Kong Polytechnic University, Hong Kong, pp. 1 - 25, 2014. 
[43] P. A. Rogerson, Statistical Methods for Geography, 1st Edition, Sage Publications Ltd. 6 Bonhill Street, London EC2A 4PU, pp. 87 - 103, 2001.

[44] Y. K. Singh, Fundamental of Research Methodology and Statistics, New Age International (P) Limited 4835/24, Ansari Road, Daryaganj, New Delhi-110002, pp. $304-$ 308, 2006.

[45] D. I. Ekine, and M. E. Onu, Economics of Small-Scale Palm Oil Processing in Ikwerre and Etche Local Government Areas of Rivers State, Nigeria, Journal of Agriculture and Social Research, Vol. 8, (2), pp. 150 - 158, 2008. 